\title{
Sejarah Novel Sejarah Indonesia: Komunikasi antara Dunia Sastra dengan Dunia Nyata
}

\author{
Heru Marwata"
}

"Penulls adalah dosen tetap di Jurusan Sastra Indonesia Fakultas Ilmu Budaya UGM Yogyakarta.

Abstract: Literary works bring their spiit of age. Its mean that literary works cant be separated from certain time context. So, there's communication between literary and realith. Then, can we use "history" on literary works as a source of history? Several people agree that literary can be positioned as mental fact. Therefore, with certain consideration, with certain fitter, and comparison and evaluation process, there's chance that literary, or historical fact inside literary works, being used as one secondary historical source. Keywords: Indonesian historical novel, Literary works, history, reallity.

\section{PENGANTAR: PROBLEMATIKA ISTILAH}

Ketika kita berbicara mengenai komunikasi, tidak bisa tidak, kita sudah membayangkan adanya korelasi positif atau bahkan interaksi antara dua pihak atau lebih. Demikian pula halnya ketika tulisan kecil ini diberi subjudul Komumikasi ... Sebagai konsekuensinya, perunutan atau pencarian hubungan antara Sastra sebagai dunia imajiner (dunia imajinasi), dunia khayal, dunia angan-angan, dengan Kenyataan (Dumia Nyata) sebagai realitas merupakan kerja tambahan yang harus dilakukan. Meskipun demikian, tentu saja kerja sampingan itu sudah tidak berat lagi karena usaha ke arah itu sudah banyak dilakukan, hasilnya sudah banyak dibukukan, dan pengakuan atasnya pun sudah hampir bisa dikatakan tidak terhitung lagi jumlahnya. Konsep bahwa sastra merupakan salah satu sarana komunikasi antara pengarang dengan pembaca, misalnya, juga telah diakui oleh banyak ahli. Tidak ada masalah. Sementara itu, judul Sejarah Novel Sejarah Indonesia sengaja dipilih karena dari istilahnya saja sebenarnya sudah mengandung problematika. Dari judul itu setidaknya dapat dibicarakan beberapa konsep atau istilah turunan berikut.

\section{SEJARAH INDONESIA}

Seperti yang telah tergores dalam catatan yang tebal dan penuh mutiara (bahkan luka, darah, dan air mata), tentu sejarah Indonesia bukan lagi barang baru yang perlu diperdebatkan. Kalau pun ditemukan beberapa hal yang dirasa mengganjal atau menggelinjang, tentu bagian itu tidaklah banyak, dan biasanya cenderung menjadi bahan perbincangan sesaat atau beberapa saat saja. Selebihnya, hampir dapat dikatakan bahwa semua yang terjadi di sini, di negeri ini, relatif telah "menyejarah". Dari sesuatu yang telah menyejarah itu juga tampak betapa hubungan antara sastra dengan realitas historis demikian dekatnya. Bahkan, dalam beberapa hal, hubungan itu demikian saling mempengaruhi.

\section{NOVEL INDONESIA}

Novel adalah salah satu genre sastra yang cukup banyak ditulis dengan menggunakan repertoar atau repertoire (terminologi Wolfgang Iser untuk menyebut "realitas ekstratekstual" dalam istilah Holub) peristiwa historis. Meskipun demikian, tidak berarti bahwa genre sastra lainnya, seperti puisi dan naskah drama, tidak memanfaatkan aspek sejarah. Mengapa novel yang dipilih sebagai bahan diskusi? Dalam kasus ini novel dipandang memiliki lebih banyak keleluasaan karena secara umum hampir semua unsur sastra (dalam istilah Robert Stanton sering disebut tema, fakta, dan sarana sastra) dapat diekspresikan secara rinci dan lebih gamblang dalam novel. Dalam beberapa hal novel juga lebih menyediakan "ruang" 


\section{JURNAL DAKWAH DAN KOMUNIKASI}

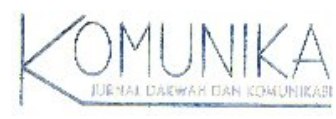

dibandingkan puisi, cerpen, atau naskah drama. Demikian pula halnya dalam kerangka komunikasi antara dua dunia: sastra dan realita.

\section{SEJARAH NOVEL INDONESIA}

Buku sejarah sastra Indonesia pernah ditulis, misalnya oleh Ajip Rosidi. Buku-buku sejenis karya Aj̈p juga telah dipublikasikan. Sebagai bagian dari karya sastra Indonesia novel tentu saja juga ikut menjadi bahan bahasan buku-buku tersebut. Apakah yang dimaksud dengan "sejarah sastra"? Apakah pustaka yang berisi periodisasi serta daftar pengarang dan karya-karyanya merupakan buku sejarah sastra? Ada ahli yang mengajak (karena merasa perlu) kita menafsir ulang model penulisan sejarah sastra yang demikian itu. Tertarik?

\section{NOVEL SEJARAH (INDONESIA)}

Dalam bahan pemicu diskusi tertulis ini novel sejarah diberi batasan sebagai novel yang memanfaatkan "sejarah" sebagai bahan penulisan, terlepas dari ada tidaknya pengakuan penulis. Adakah novel seperti itu di Indonesia? Jika dikaitkan dengan label resmi, misalnya berupa tulisan Novel Sejarah (di sampul, misalnya), memang sangat sedikit contohnya. Di antara yang sedikit itu trilogi Rara Mandut, Genduk Duku, dan Lusi Lindri karya Mangunwijaya merupakan contoh konkret. Namun, jika dasarnya bukan label, melainkan tanggapan atau pengakuan orang-orang yang berkompeten dalam bidang sastra (saat ini kebanyakan tanggapan/pengakuan seperti itu dimuat/disertakan dalam novel, misalnya di sampul dalam atau belakang, endorsemen), contoh karya yang dapat dimasukkan ke kriteria novel sejarah jumlahnya cukup banyak. Novel-novel karya Pandir Kelana dan Trilogi Gadis Tangsi Suparto Brata dapat disebut sebagai contoh. Juga salah satu di antara karya Pulau Buru Pramoedya. Bagaimana novel-novel itu "memakai" sejarah atau berkomuniksai dengan realitas historis? Apakah dengan demikian berarti "sejarah novel-sejarah" dapat disusun? Atau, jangan-jangan justru sebenarnya semua novel Indonesia adalah novel sejarah. Ini sebuah tantangan bagi para penulis sejarah sastra dan sejarah umum.

\section{SEJARAH NOVEL DAN SEJARAH INDONESIA}

Tesis keempat Hans-Robert Jauss yang terkenal adalah Semangat Zaman (lengkapnya 7 tesis itu adalah; (1) pengalaman pembaca, (2) horison harapan, (3) jarak estetik, (4) semangat zaman, (5) rangkaian sastra, (6) sinkronis dan diakronis, serta (7) sejarah khusus dan sejarah umum). Dalam penjelasan konsep semangat zaman ditemukan semacam kesimpulan bahwa karya sastra membawa semangat zamannya. Arti mudahnya, karya sastra membawa "semangat zaman" ketika karya itu ditulis. Hal ini merupakan indikasi pengakuan bahwa karya sastra tidak bisa dilepaskan dari konteks waktu tertentu, lebih mudahnya lagi antara sastra dan realitas terjadi komunikasi. Sejarah novel (Indonesia) tidak dapat dicerabut dari akar sejarah (Indonesia). Jika logikanya di balik, sejarah (Indonesia) telah (bahkan, pasti) "mewarnai" sejarah novel (Indonesia). Dengan logikayang muluk-muluk, tentu tidak tertutup kemungkinan bahwa novel Indonesia juga punya peluang atau potensi untuk mempengaruhi sejarah Indonesia. Pernah-kah kita menyadari bahwa seri Bumi Mamusia Pramoedya Ananta Toer (AnakSemua Bangsa, Jejak Langkah, dan Rumah Kaca) pernah “mewarnai” sejarah Indonesia?

Semangat zaman adalah bagian dari sejarah. Apa fungsi aspek historis itu bagi novel? Membuat jarak estetik antara karya dan pembaca tidak terlalu renggang. Mengapa? Agar yang ada dalam karya itu tidak menjadi asing dan tidak dikenali pembaca. Bagaimana dengan "kata mutiara" yang mengatakan bahwa sastra selalu berada dalam ketegangan antara tradisi dan inovasi dan bahwa karya sastra dinilai atau dihargai karena kebaruan atau invensinya? Untuk menjawabnya, karena sudah telanjur menyebut secara lengkap, sebaiknya kita membawa kisah ini kekonteks 7 tesis Jauss.

Hubungan ketujuh tesis Jauss di atas bersifat dialektis. Secara berurutan, tesis pertama menjadi dasar tesis kedua, demikian seterusnya. Pengalaman baca seseorang akan mempengaruhi horison harapannya. Horison harapan yang dilandasi oleh pengalaman baca itu akan menentukan renggang rekatnyajarak estetik yang terjadi antara karya sastra dengan pembaca, dan seterusnya. Karya sastra membawa semangat zaman. Karya sastra berada dalam rangkaian sastra. Karya sastra berposisi 


\section{JURNAL DAKWAH DAN KOMUNIKASI}

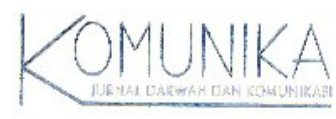

dalam penampang sinkronis dan diakronis. Karya sastra juga berada dalam konteks sejarah khusus dan sejarah umum. Tujuh tesis Jauss sebenarnya dapat dikatakan sebagai tesis komunikasi antara sastra dan kenyataan sejarah, antara dunia imajinasi dengan realitas historis.

Sayang memang bahwa kadang-kadang horison harapan pembaca tidak hanya dipengaruhi oleh pengalaman baca, tetapi juga oleh "kepentingan tertentu". Akibatnya, karya-karya yang ditengarai berpotensi mempengaruhi "keinginan" dan "keingintahuan" pembaca jusru harus menerima tempelan label tertentu: salah satu label yang paling menakutkan adalah Dilarang. Era berganti, masa berlalu, tanggapan orang pun mengalami perubahan, dan label terhadap karya tertentu juga bisa diklethek seperti stiker. Dari uraian yang terbatas ini ada indikasi kemungkinan karya sastra mampu pula "menyemangati zaman" (bukan hanya membawa semangat zaman).

Sebagai ilustrasi, cermati kutipan pendapat Jakob Sumarjo dari halaman akhir roman Anak Semua Bangsa karya Pram berikut. "Kita beruntung menyaksikan novel besar pada dekade ini ... yang ... telah berhasil menggambarkan suasana sosial budaya zamannya." Secara implisit jelas dalam pernyataan ini ada pengakuan antara sastra sebagai gambaran dunia dengan dunia (nyata) yang dilukiskannya.

\section{SEJARAH NOVEL SEJARAH DAN SEJARAH INDONESIA}

Dalam uraian sebelumnya disajikan semacam penjajaran antara Sejarah Novel dan Sejarah Indonesia. Dengan "semangat" yang sama pendampingan "Sejarah Novel Sejarah" dan "Sejarah Indonesia" pun pasti berterima. Sanusi Pane menulis Surapati dan Robert Anak Surapati sertaSandyakalaning Majapahit pada tahun 30-an. Apakah ada korelasi antara karya-karya Sanusi Pane dengan sejarah bangsa kita? Tampaknya sangat sulit untuk menolak atau menisbikan adanya hubungan tersebut.

\section{NOVEL SEJARAH TENTANG INDONESIA}

Dalam sejarah novel Indonesia dikenal beberapa judul berikut. Rara Mendut (Balai Pustaka), Rara Mendut (Aj̈p Rosidi), Rara Mendut (Mangunwijaya). Jika dalam ketiga novel itu disebut-sebut nama tempat seperti Kerajaan Mataram dan Pati serta nama-nama tokoh seperti Sultan Agung, Adipati Pragola, dan Tumenggung Wiraguna, adakah artinya bagi sejarah? Burung-burung Manyar karya Mangunwijaya, misalnya, menyebut-nyebut nama UGM \{ketika tokoh fiktif Larasati mendapatkan gelar doktor dengan predikat summa cum laude di Balai Senat (pernah terjadikah dalam sejarah UGM?)\}, menggunakan tiga latar waktu (prarevolusi, revolusi, dan pascarevolusi) penting di Indonesia, serta memasukkan tokoh Sjahriryang terkenal. Adakah korelasi positifantara karya itu dengan sejarah Indonesia?

Mengapa karya Ki Panji Kusmin Langit Makin Mendung pernah menghebohkan dunia sastra Indonesia pada tahun 60-an? Mengapa Senja di Jakarta Mochtar Lubis dinilai mengritik Soekarno? Mengapa Para Priyayi dan Jalan Menikung serta Sri Sumarah karya Umar Kayam direkomendasikan untuk dibaca oleh orang (asing) yang ingin mengetahui seluk beluk orang (dan budaya) Jawa? Lasi-yang seperti orang Jepang_dalam Bekisar Merah karya Ahmad Tohari dijadikan istri simpanan oleh seorang pejabat yang merasa perlu-karena gengsi-meniru "gaya kawin" sang pemimpin besar revolusi. Apakah ini sebuah pertanda betapa cukup positifnya hubungan atau betapa terjalin eratnya komunikasi antara sejarah dan sastra atau antara sejarah sastra dan sejarah bangsa?

\section{SEJARAH DALAM NOVEL (SEJARAH)}

Perhatikan beberapa kutipan berikut.

Roro Mendut ... dicipta baru dalam bentuk sastra dengan versi khas ... Tanpa meninggalkan pertanggungiawaban segi-segi historisnya yang dilandaskan pada studitentang Babad Tamah Jawi, dokumen-dokumen .... (sampul belakang novel Roro Mendut karya Mangunwijaya). 


\section{JURNAL DAKWAH DAN KOMUNIKASI}

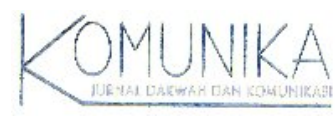

Apakah ini berarti bahwa dalam karya fiksi yang bergenre novel, khususnya novel sejarah, ada muatan sejarahnya? Jika ya, sejauh mana fakta historis fiksional itu bisa dianggap sebagai sebuah kebenaran? Apakah itu berlaku untuk semua karya dari semua penulis?

GendukDuku ... mengungkap suasana tahun-tahun terakhir masa pemerintahan Sultan Agung ... serta suasana yang sendi-sendi historisnya dapat kita lacak dalam laporan-laporan sumber Barat, seperti yang didokumentasikan oleh bekas duta besar VOC di Mataram, ... semua itu diolah dalam ramuan cerita fiktif.... (sampul belakang novel GendukDuku karya Mangunwijaya).

Jika di sini disebutkan tentang ramuan cerita fiktif, masih layakkah kita mematok realitas imajinatif sebagai sebuah kenyataan? Dimana batas-batasnya?

... Lusi Lindri ini memantau, dalam bentuk novel sejarah, secermat mungkin data dan fakta historis Sunan Mangkurat I (abad ke-17), raja kejam Mataram dan zamannya yang penuh peristiwa dramatis. ... wilayah-wilayah (yang sekarang disebut) Bagelen, Magelang, dan Gunung Kidul .... (sampulbelakang novel LusiLindriMangunwijaya).

Bagaimana kita bisa memilih dan memilah secara tepat yang fakta sejarah dan realitas fiksional?

Novel BALADA DARA-DARA MENDUT ini sebentuk dokumentasi, bahkan monumen juga berupa sastra yang "mengabadikan" suatu lembaran sejarah perintisan .....(sampul belakang novel Balada Dara-dara Mendut karya Mangunwijaya).

Jika dikatakan mengabadikan suatu lembaran sejarah, apakah ini berarti bahwa semua yang dibeberkan adalah nyata adanya?

Perhatikan beberapa hal dan "fakta" berikut.

Suparto menikah dengan Rr. Ariyati, anak seorang petani kaya di Ngombol, Kedu Selatan. Rr. Ariyati lahir di Meurudu 1940, ketika ayahnya jadi serdadu kumpeni. Ketika Perang Dunia II meletus, ayahnya dibubarkan dari kumpeni di Bandung, sedangkan Ariyati bersama tiga orang saudaranya serta ibunya tertinggal bersama istri serdadu kumpeni lainnya di asrama tangsi Medan. Mereka dibawa mengungsi oleh tentara Belanda, tetapi terkejar oleh tentara Jepang di Blankejeren (biografi singkat Suparto yang dimuat di halaman terakhir trilogi novelnya) (realitas historis).

Bandingkan biografi di atas dengan "fakta" yang ada dalam novel Suparto ini.

Tokoh utama Trilogi Gadis Tangsi adalah Teyi. Adik Teyi, Tumpi, lahir di Meurudu. Tangsi Lorong Belawan berada di Medan. Ayah Teyi seorang serdadu kumpeni. Setelah ayahnya tewas dan Belanda mengalami kekalahan dari tentara Jepang, Teyi, Tumpi, dan ibunya bersama dengan istri-anak para serdadu kumpeni diungsikan oleh tentara Belanda. Rombongan pengungsi ini terkejar tentara Jepang di Blankejeren dan dijadikan tawanan. Akhirnya, keluarga Teyi yang berasal dari Ngombol bisa selamat kembali ke daerah asal. Teyi dan ibu serta adiknya sukses membangun Kerajaan Raminem (nama ibu Teyi) di Ngombol, menjadi tuan tanah dan juragan padi-beras (realitas fiksional).

Perhatikan kutipan ini.

"Narasumber novel Kerajaan Raminem adalah mertua Suparto Brata" (Kerajaan Raminem, 2006: 470). "Narasumber novel Mahligai di Ufuk Timur ini adalah kesaksian, pengalaman, dan pengamatan Suparto Brata sendiri, asli dan murni” (sampul belakang Mahligai di Ufuk Timur, 2007). Ketika kita mencermati kata "narasumber", terbayanglah adanya sebuah Isi yang memerlukan Bentuk. Yang disampaikan mertua Suparto adalah Isi, dan yang ditulis Suparto dalam triloginya adalah Bentuk itu, yang lengkap dengan isinya dalam bentuk yang agak lain. Di sini ada dua realitas yang berbeda. Yang disampaikan mertua Suparto (kemungkinan besar) adalah realitas historis, sementara yang di-jlentreh-kan Suparto dalam triloginya adalah realitas fiksional. Demikian pula halnya ketika Suparto sendiri menjadi narasumber bagi novel yang ditulisnya.

Dapatkah kita memanfaatkan "sejarah" dalam karya sastra sebagai salah satu sumber sejarah? Ada beberapa orang yang bersepakat bahwa sastra dapat didudukkan sebagai fakta mental. Jadi, dalam beberapa hal, dengan berbagai pertimbangan, dengan filter tertentu, lewat proses komparasi dan evaluasi, sebenarnya tidak tertutup kemungkinan sastra, atau fakta historis dalam sastra, digunakan sebagai salah satu sumber sejarah (sekunder).

Dulu, sebut saja novel-novel sebelum tahun 80-an, karya sastra yang menampilkan adegan yang dekat-dekat dengan seksualitas dianggap agak tabu. Bahkan, ada tokoh yang mensinyalir karya sastra dianggap sebagai pose pengarangnya di depan publik. Akibatnya, hampir tidak ada sastrawan yang ingin dicap suka berpose "porno" di hadapan khalayak, meskipun 


\section{JURNAL DAKWAH DAN KOMUNIKASI}

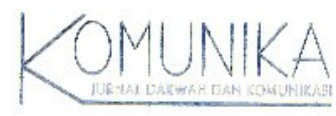

hanya lewat karyanya. Sekarang, sebut saja karya-karya para pengarang wanita seperti Ayu Utami, Djenar Maesa Ayu, Fira Basuki, dan Dewi Lestari, "pose” yang dulunya dianggap agak melanggar ketabuan justru ditengarai sedang ngetren. Sekadar tambahan informasi mengenai pose pengarang ini, beberapa waktu yang lalu UNY nanggap artis Ria Irawan untuk membacakan Vagina Monolog (dan ternyata diikuti oleh seorang peserta reuni FIB UGM dengan membacakan Vagina Monolog di Pendapa Rumah Dinas Bupati Sleman, edan ora?). Masa berganti, rezim bergulir, dan kita mungkin-jika dianugerahi umur panjang-akan menyaksikan wolak-waliking jaman karena yang dianggap baik dalam kriteria sekarang, belum tentu bertahan di era yang telah berubah. Bukankah dalam sejarah juga pernah terjadi fenomena serupa? Bukankah gonta-gantinya buku teks sejarah merefleksikan adanya peristiwa tersebut? Kita lihat saja.

\section{FAKTA DAN FIKSI: REALITA(S) DAN IMAJINASI -> KOMUNIKASI}

Dalam konteks hubungan antara fakta dan fiksi, di manakah pengarang berposisi? Menurut teori strukturalisme-genetik sosiologi sastra Lucien Goldmann pengarang bukanlah individu, ia transindividu, menulis dengan pandangan dunia tertentu. Sebagai subjek transindividu pengarang "berbicara" (termasuk melalui karya sastra) atas nama kelompok tertentu atau kelompoknya (disadariatau tidak).

Konon, pengarang (apalagi pengarang besar/utama) termasuk kelompok orang yang memiliki kepekaan, daya perenungan, dan sekaligus kekuatan berimajinasi yang relatif tinggi. Ketika "berbicara" pengarang tidak hanya menyampaikan informasi atau fakta secara wantah, tetapi telah "membumbuinya" dengan pandangan, pikiran, harapan, serta misi dan visi tertentu. Bagi seorang "koki" fiksi, fakta adalah bahan mentah yang harus diolah agar siap saji, syukur-syukur dengan aroma yang merangsang indera, dengan performa yang mempesona, dengan citarasa yang memanjakan penggemarnya, dan dengan berjuta maksud yang belum tentu dapat kita raba-duga.

Makin tinggi kemampuan sang koki fiksi dalam berimajinasi, makin tinggi pula kemungkinan fakta mentah yang diolahnya menjadi demikian mengundang selera (baca), dan dengan demikian, makin mudah pulalah komunikasi antara sastra dan realitas terjalin manis. Dalam konteks ini, semakin besar pulalah probabilitas karya cipta itu "menyejarah" dan mempengaruhi sejarah. Benarkah?

\section{PENUTUP: APOLOGI}

Demikian sekadar pemicu diskusi tertulis yang dapat disajikan mengenai komunikasi antara sastra dan realitas, antara dunia angan dengan kenyataan, antara dunia ciptaan pengarang dengan dunia hidup pengarang. Dengan mempertimbangkan beberapa uraian dan sekaligus bukti yang penulis coba beberkan, tampaknya mengakui adanya komunikasi antara dua dunia, sastra dan sejarah, bukanlah pengakuan yang tanpa dasar. Terlalu banyak bukti yang dapat dikemukakan sebagai pendukung atas pengakuan itu. Bagaimana dengan Anda?

\section{DAFTAR PUSTAKA}

Ananta Toer, Pramoedya. 1980. Bumi Manusia. Jakarta: Hasta Mitra.

. 1980. Anak Semua Bangsa. Jakarta: Hasta Mitra.

. 1980. Rumah Kaca. Jakarta: Hasta Mitra.

Brata, Suparto. 2004. Gadis Tangsi. Jakarta: Kompas.

2006. Kerajaan Raminem. Jakarta: Kompas.

. 2007. Mahligai di Ufuk Timur. Jakarta: Kompas.

Barthes, Roland. 1990. S/Z. United Kingdom: Basil Blackwell Ltd.

Goldmann, Lucien. 1975. Towards a Sociology of the Novel. London: Tavistock Publication Ltd.

Holub, Robert C. 1989. Reception Theory: A Critical Introduction. London: Routledge.

Iser, Wolfgang. 1987. The Act of Reading: A Theory of Aesthetic Response. Baltimore \& London: The John Hopkins University Press.

Jauss, Hans Robert. 1983. Toward an Aesthetic of Reception. Minneapolis: University of Minnesota Press. 


\section{JURNAL DAKWAH DAN KOMUNIKASI}

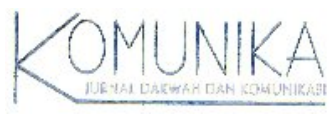

Mangunwijaya, Y.B. 1993. Balada Dara-dara Mendut. Yogyakarta: Kanisius.

. 1994. Rara Mendut. Jakarta: Gramedia Pustaka Utama.

. 1994. Genduk Duku. Jakarta: Gramedia Pustaka Utama.

. 1994. Lusi Lindri. Jakarta: Gramedia Pustaka Utama.

. 1986. Bunung-bunung Manyar. ?: Djambatan.

Stanton, Robert. 1964. An Introduction to Fiction. New York: Holt, Rinehart and Winston, Inc. 